UNIVERSITY OF GOTHENBURG

SCHOOL OF BUSINESS, ECONOMICS AND LAW

WORKING PAPERS IN ECONOMICS

No 562

Amenity Values of Proximity to

National Wildlife Refuges:

An analysis of urban residential property values

\author{
Xiangping Liu \\ Laura Taylor \\ Timothy Hamilton \\ Peter Grigelis
}

March 2013

ISSN 1403-2473 (print)

ISSN 1403-2465 (online) 


\title{
Amenity Values of Proximity to National Wildlife Refuges: An Analysis of Urban Residential Property Values
}

\author{
Xiangping Liu \\ Department of Economics \\ University of Gothenburg \\ Laura Taylor \\ Center for Environmental and Resource Economic Policy \\ North Carolina State University \\ Timothy Hamilton \\ Department of Economics \\ University of Richmond \\ Peter Grigelis \\ Office of Policy Analysis \\ U.S. Department of the Interior
}

\begin{abstract}
The National Wildlife Refuge system is a network of permanently protected open space encompassing more than 150 million acres across 50 states. Maintaining such a large network of permanently protected open space can put the federal government at odds with local communities when management priorities differ from the local community's objectives. This can be especially true in rapidly urbanizing areas where local jurisdictions voice concerns over the loss of property tax revenues and economic activity resulting from lands' protected status. While refuge recreation and ecosystem benefits have been identified, we know little about the property value benefits accruing to local homeowners. This research quantifies the property value benefits of all refuges on the east coast that are near urban areas. Our approach is made possible through access to confidential U.S. Census data identifying property values surrounding all refuges with high geographic resolution. Results from hedonic property value models suggest that the amenity values of refuges located near urbanized areas are capitalized into the value of homes in very close proximity, averaging $\$ 11$ million per refuge. These capitalized values add directly to the local tax base and are considerable complements to the annual economic value created by the refuge system.
\end{abstract}

Keywords: National Wildlife Refuges, open space, amenity values, hedonic analysis

JEL codes: Q24, Q51, Q57, Q58

Acknowledgements: We wish to thank the U.S. Fish and Wildlife Service Division of Economics for funding under cooperative agreement G09AC00299. The authors wish to thank the Center for Environmental and Resource Economic Policy at North Carolina State University for partial support of this research. In addition, Liu acknowledges the financial support from BECC and COMMONS Human Cooperation to Manage Natural Resources during the final stages of this research. The contents are solely the responsibility of the authors and do not necessarily reflect the official views of the U.S. Fish and Wildlife Service or the Department of the Interior. This research was conducted while the authors were Special Sworn Status researchers of the U.S. Census Bureau at the Triangle Census Research Data Center. Any opinions and conclusions expressed herein are those of the authors and do not necessarily represent the views of the U.S. Census Bureau. All results have been reviewed to ensure that no confidential information is disclosed.. 


\section{Amenity Values of Proximity to National Wildlife Refuges: An Analysis of Urban Residential Property Values}

\section{Introduction}

The federal government manages a vast network of public open space across the U.S. Over 693 million acres spanning all 50 states are under the jurisdiction of the U.S. Department of Interior and the U.S. Forest Service, and are managed for a variety of purposes ranging from timber production and livestock grazing to the provision of public recreational opportunities, preservation of historical and cultural resources, and species and habitat protection. This diversity of land management responsibilities results in the federal government having direct and indirect relationships with many communities and private entities. The nature of these relationships can be the subject of vigorous debates, especially when the management responsibilities charged to federal agencies from specific laws and regulations are at odds with the local community's desired outcomes. For example, land conservation policies can be opposed by local communities who argue that placing areas in a protected status hinders local economies by keeping potentially valuable resources out of development or other direct economic uses. However, land conservation proponents emphasize the importance of available recreational activities, the natural amenities offered to local residents, and the overall suite of ecosystem services that protected open spaces provide (Duffy-Deno, 1998; Deller et al., 2001; Lewis, et al., 2002; ).

Among the federal land management agencies, the U.S. Fish and Wildlife Service (USFWS) within the Department of Interior is somewhat unique in that it has an explicit mission to conserve fish, wildlife, plants and their habitats. To help fulfill its mission, the USFWS manages the National Wildlife Refuge system, a network of over 550 refuges in 50 states that encompass more than 150 million acres of permanently protected open space. The guiding management principles of the refuge system are centered on the conservation of species and habitat, while also allowing for compatible recreational use. Along the eastern U.S., many refuges are located near coastal and other highly-urbanized areas which creates a unique set of challenges for the USFWS. Coastal populations have steadily increased over the past several decades resulting in dense population centers and increased development pressures on undeveloped lands. As a result, further attention is drawn to the opportunity costs associated 
with the permanently protected open space offered by refuges and the USFWS's interaction with the surrounding local communities.

While the benefits associated with recreational opportunities that many refuges afford have been recognized by local communities and USFWS (See Carver and Caudill, 2007), a common concern expressed by local government officials is that refuges reduce the local tax base since refuge lands are not subject to property taxes. Local jurisdictions do receive direct payments from the USFWS to offset the reduction in property tax revenues for federally owned land, although these payments are usually quite small. ${ }^{1}$ What is typically not recognized by local communities is that permanently protected open space can directly benefit local communities by increasing the value of nearby residential land, and thus also indirectly support the tax base.

As with other types of open space, refuges could positively affect nearby property values. The permanent nature of refuges provides protections against future development and preservation of valuable ecosystem services (e.g., aesthetic amenities). The positive influence of proximity to open space on property values has long been recognized in the literature (see McConnell and Walls (2005) for an extensive literature review), and refuges can be expected to offer these same benefits. The potential impacts of refuges on nearby residential properties may be particularly apparent in densely populated areas of the eastern U.S. where people may place a premium on being located near permanently protected refuge lands (Cho et al., 2008, Anderson and West, 2006). While it is difficult to fully ascertain the degree to which refuge spillover benefits could replace tax revenues associated with alternative development of refuge lands, quantifying the magnitude of in-situ refuge benefits is an important component of the overall economic value of the nation's systems of preserved open space.

In this research, the potential economic benefits of the refuge system along the eastern U.S. are estimated. A unique database of parcel-level housing data around every refuge near urbanized areas is assembled that allows us to take a 'programmatic view' and estimate the average effect of proximity to a refuge across all refuges under the USFWS jurisdiction. Our approach is unique in the hedonic valuation literature on open space as previous studies typically choose a relatively small geographic area such as a county or single urban area and explore the impacts of diffuse open space as it is distributed across the landscape (e.g., Bark et al., 2009,

\footnotetext{
${ }^{1}$ Local jurisdictions receive direct payment in lieu of taxes according to the Refuge Revenue Sharing Act (see http://www.fws.gov/refuges/realty/rrs.html).
} 
Cho, et al., 2009, Anderson and West, 2006, Geoghegan et al., 2003, Acharya and Bennett, 2001, Bolitzer and Netusil, 2000). Our programmatic approach is made possible with access to confidential micro-level census data from the 2000 U.S. Census. The confidential data provides detailed information on housing characteristics and owner-assessed values for a one-in-six sample of all households in the U.S. and importantly, identifies the location of each house at a very fine geographic resolution. The comprehensive geographic coverage of the data combined with its fine spatial resolution allows us to investigate the influence of all managed lands under the USFWS jurisdiction while accurately measuring other important spatially varying features such as transportation corridors, water bodies and other forms of open space besides refuges. By identifying the benefits specific to a comprehensive set of open space lands under one agency's jurisdiction, we provide quantitative evidence that is directly useful for federal analysis of an important system of permanently protected open spaces.

Hedonic price models are estimated and indicate that refuges provide substantial benefits to homeowners in urbanized areas. Homes located in very close proximity to a refuge $(<0.5$ miles) and within eight miles of an urban center are estimated to be valued between approximately five and ten percent higher than homes further away. The capitalized value of these benefits is estimated to average $\$ 11$ million per refuge for homeowners located within 0.5 miles of a refuge and within eight miles of an urban core. Capitalized values are estimated to be as high as $\$ 50$ million for individual refuges located in densely population areas (all estimates are in 2010 dollars). These capitalized values can translate to property tax revenue increases of up to $\$ 1$ million per annum for local jurisdictions given tax rates as high as 20-30 mils in many states (e.g., Florida, New York and New Jersey). For comparison, Carver and Caudill (2006) estimate the net economic value of recreational visits to all refuges (with more than 1,500 visitors per year) in the northeast and southeast regions to average approximately $\$ 2$ to $\$ 3$ million per refuge. Thus it would appear that the property value benefits associated with refuges have the potential to be a significant component of the overall annual economic value generated by the refuge system.

\section{The National Wildlife Refuge System}

The Refuge system is national network of federally protected lands managed by the USFWS specifically for the conservation of fish, wildlife, plants, and their habitats, while also 
allowing for compatible wildlife-dependent uses (e.g., hunting, fishing, wildlife observation, photography, interpretation, and education). Refuges are estimated to provide habitat for more than 1,300 species of plants and animals, of which more than 250 are threatened or endangered. Many refuge lands also serve as important nesting and breeding grounds for migratory waterfowl. Nationally, over 40 million visitors are estimated to visit refuges each year and their expenditures help support local businesses as well as generate important sale tax revenues for local governments, thereby forming a direct link between refuges and the economic profile of surrounding communities.

The refuges included in this research include all those along the eastern U.S. that are also within close proximity of urbanized areas. As compared to other regions of the U.S., the east coast is home to many refuges that are proximate to areas with sufficiently dense housing to expect that the provision of open space would be capitalized into nearby residential land values. ${ }^{2}$ Specifically, the sample of refuges includes those that have a boundary within two miles of an urban area boundary (as defined by the U.S. Census) and were established before 2000, the year in which the housing data used in the analysis are recorded. ${ }^{3}$ There are 59 refuges located in 15 eastern states that met these requirements. Collectively, these refuges encompass more than 360,000 acres of permanently protected open space.

Summary statistics for the 59 refuges are reported in Table 1 . The refuges are delineated by the administrative service region in which they are located. The northeastern service area includes all coastal states from Virginia northward, while the southeastern service area includes North and South Carolina, Georgia and Florida. As indicated in Table 1, there is considerable heterogeneity in refuge size across the sample, and on average, refuges tend to be larger and established more recently in the southeast as compared to the northeast. The majority of refuges are open to the public, and approximately $20 \%$ include roads for automobile touring. Visitation rates of refuges were also provided by the USFWS and show considerable heterogeneity.

Table 1 also presents a few key summary statistics of the urbanized areas that are in close proximity to the refuges. The mean urban area size in terms of geography and population is

\footnotetext{
${ }^{2}$ This requirement is supported by Boyle, Patterson and Poor (2002) who conduct a case study of four refuges and are not able to robustly identify impacts for the refuges that are located in more rural areas.

${ }^{3}$ An urban area is defined by U.S. Census as contiguous, densely settled census block groups and census blocks that meet minimum population density requirements and that together encompass a population of at least 50,000 people. Geospatial information for the U.S. Census defined urban areas is publicly available from the U.S. Census website (see http://www.census.gov/geo/www/ua/ua_2k.html for more details, last accessed February, 2013). Refuge boundaries were provided directly by the USFWS.
} 
larger in the northeast than the southeast. The urbanized areas near the refuges are densely settled, with an average of approximately 3,000 and 2,000 people per square mile in the northeast and southeast, respectively. Total housing units and mean housing density follow a similar pattern, again with refuges in the northeast being located near larger urban areas with somewhat denser housing.

\section{Residential Housing Data}

Data on individual housing units are obtained through access to confidential census micro-data at the Triangle Census Research Data Center. The micro-data contain the individual responses of homeowners to the U.S. Census Long Form. The Long Form was distributed to one in six households in the 2000 census and collected information on the household's dwelling including the owner's assessment of the dwelling's value and a number of property features such as the number of rooms and the age of the home. Importantly, the micro-level survey responses are geographically identified by their census block, the smallest spatial unit designated by Census. Census blocks roughly represent a physical "block" as defined by streets, roads, rivers, or other natural boundaries, but do vary some in geographic size and population due to the spatial nature of the features that define them. The ability to geographically identify individual homes by their census block location allows us to measure each home's proximity to a refuge with reasonable accuracy. Census further aggregates blocks into block-groups and tracts, which are meant to represent populations that have similar characteristics - i.e., "neighborhoods". ${ }^{4}$

We expect the impacts of proximity to a refuge to be highly localized, and thus our final sample of housing units includes only those whose census block centroid is within 3 miles of a refuge. This selection criteria results in a total of 87,568 individual housing units being available for analysis surrounding the 59 refuges. The number of housing units around any single refuge varies from 4,660 to 18,134 homes.

Definitions and summary statistics for the variables collected by the Census that describe housing units are reported in Table 2. The reported summary statistics for variables describing housing and neighborhood characteristics are based on publicly available Census data provided at the block-group level of geography rather than our sample of individual housing units due to

\footnotetext{
${ }^{4}$ Block groups generally represent 600 to 3,000 individuals and tracts are aggregations of block groups to populations generally between 1,500 and 8,000 people.
} 
confidentiality of the data. Specifically, the average of the block group means for each variable is computed over all block groups within 3 miles of a refuge. The means are similar when computed over block groups or over individual housing units.

As indicated in Table 2, the mean housing value is substantially higher in the northeast as compared to the southeast (\$195,000 vs. $\$ 114,000$ in 2000 dollars), although the number of rooms and bedrooms are similar across the northeast and southeast samples. ${ }^{5}$ Not surprisingly, mean population density is substantially lower in southeast than in the northeast, however other neighborhood characteristics are similar across regions. The average family size is larger in the northeast, and household income is higher in the northeast. The occupancy status of homes are similar across the northest and southeast samples, as are the type of housing (single-family detached versus apartments and other).

The last two panels of Table 2 report summary statistics for the geographic descriptors of the housing sample. Reported mean distances to features of interest are based on the distance of the centroid of each home's census block to the boundary of the nearest refuge, urban area, state or national park, interstate highway, or major body of water (including oceans). As indicated in Table 2, the mean distance of housing to a refuge boundary is approximately 1.5 miles in the northeast and 1.7 miles in the southeast. Given our sample selection criteria that homes must be within three miles of the boundary of a refuge, it is not surprising that the mean distance between homes and the nearest refuge is approximately 1.5 miles for both the northeast and southeast. Homes in the northeast tend to be closer to other state or federal parks and highways, but further from the nearest water body and urban area as compared to homes in the southeast.

Finally, Table 2 reports summary statistics for major categories of land use that characterize a home's neighborhood. The percentage of land cover in each block group is computed for various land use categories as defined by the 2001 National Land Cover Database (NLCD). The NLCD provides coverage data for the entire U.S. and classifies each 30x30 meter parcel of land into one of 29 land use categories which are then aggregated into nine classifications summarized in the final panel of Table 2. As compared to the northeast, the southeastern sample is characterized by more developed open space and wetlands, but is less

\footnotetext{
${ }^{5}$ Although not reported in Table 2, the Census also collects the age of the structure (as a categorical variable) and the type of heating fuel used. The housing stock is older in the northeastern sample (77\% were built before 1980) as compared to the southeast where $54 \%$ were built prior to 1980 . Both age and fuel type were not statistically significant in any models estimated, and thus were not included in the final regressions.
} 
heavily developed and has less forest coverage.

\section{Empirical Strategy and Results}

Hedonic pricing models are employed to estimate the impact of proximity to a refuge on housing values (see Palmquist, 2005 and Taylor, 2003 and 2008 for reviews). The base econometric model regresses the natural log of housing value on the component characteristics of the housing, including neighborhood and location attributes:

$$
\begin{aligned}
\ln P_{i}=\alpha+\beta_{1} D_{-} \text {refuge } & +\beta_{2} D_{-} \text {refuge }{ }_{i}^{2}+R C \eta+H_{i} \delta \\
& +N_{b} \gamma+G_{b} \theta+L C_{b g} \mu+\tau_{t r}+\varepsilon_{i},
\end{aligned}
$$

where the natural $\log$ of housing price for the $\mathrm{i}^{\text {th }}$ house is assumed to be a function of its distance to the boundary of the nearest refuge (D_refuge), a vector of refuge characteristics $(R C)$, a vector of housing characteristics describing the $\mathrm{i}^{\text {th }}$ house $\left(H_{i}\right)$, a vector of neighborhood characteristics measured at the block level $\left(N_{b}\right)$, a vector of geographic descriptors of the census block in which the house is located $\left(G_{b}\right)$, a vector of variables that describe the land cover of the block-group in which the house is located $\left(L C_{b g}\right)$, and a vector of census tract fixed effects $\left(\tau_{t r}\right)$. The coefficients $\alpha, \beta, \eta, \delta, \gamma, \theta$, and $\mu$ are to be estimated, and $\varepsilon_{\mathrm{i}}$ is an error term. ${ }^{6}$ The covariates included in each vector were defined and summarized in Table 2.

Given the specification in equation (1), a negative coefficient estimate is expected for $\beta_{1}$ since we hypothesize that housing value will decrease the further a house is from a refuge, all else equal. In addition, we expect a positive estimate for $\beta_{2}$ to capture diminishing returns to proximity as parcels are further from a refuge. In addition to the specification in (1), alternative ways to model the impact of distance to a refuge on housing values are considered. Models are also estimated in which proximity to a refuge is measured in six one-half mile intervals:

$$
\begin{aligned}
& \ln P_{i}=\alpha+\beta_{1} D 0.5_{i}+\beta_{2} D 1.0_{i}+\beta_{1} D 1.5_{i}+\beta_{1} D 2.0_{i}+\beta_{1} D 2.5_{i} \\
& +H_{i} \delta+N_{b} \gamma+G_{b} \theta+C_{b g} \mu+\varphi_{\text {refuge }}+\tau_{t r}+\varepsilon_{i},
\end{aligned}
$$

where D0.5 is a dummy variable with value 1 if a house is at most 0.5 miles away from a refuge; D1.0 is equal to 1 if a house falls within a 0.5 to 1.0 mile buffer ring of a refuge; and D1.5 to D2.5 have similar definitions. Note, D3.0 is the category left out of the model and thus, for houses located within 0.5 of a refuge, $\beta_{1}$ represents the percentage increase in price given a

\footnotetext{
${ }^{6}$ All models use robust standard errors that allow for an unknown form of heteroskedasticity.
} 
house is within 0.5 as compared to being located between 2.5 and 3.0 miles from the refuge. The remainder of the variables in equation (2) are as defined in equation (1). Finally, we also report models that only include the categorical variable D0.5:

$$
\ln P_{i}=\alpha+\beta_{1} D 0.5_{i}+H_{i} \delta+N_{b} \gamma+G_{b} \theta+C_{b g} \mu+\varphi_{\text {refuge }}+\tau_{t r}+\varepsilon_{i} .
$$

This specification is appropriate to capture the average effect of very close proximity if the amenity effects of proximity to a refuge diminish rapidly beyond 0.5 miles. Additional specifications were estimated that included the natural log transformation for distance to a refuge and a specification that included a dummy variable equal to one if a home is within 1 mile of a refuge and zero otherwise. Results for these models are consistent with results reported here.

As with any empirical investigation, the validity of the hedonic estimates rely on the quality of the data upon which the results are based. Perhaps the most important threat to validity in hedonic property value models is the potential for spatially-varying unobservable variables that are correlated with both housing values and the amenity of interest (proximity to open space in our case). In an attempt to mitigate the potential for spatially-varying unobservable characteristics, we include a rich set of spatial covariates that describe the neighborhood and land-use characteristics in a home's immediate neighborhood as well as its proximity to amenities and disamenities other than refuges. As discussed above and presented in Table 2, we include eleven neighborhood demographic characteristics, four geographic descriptors (e.g., proximity to interstate highways), and variables capturing the percentage of land near the home in nine land use categories. In addition, we employ census tract fixed-effects in a further attempt to capture potential spatially-varying unobservables. As indicated by Kuminoff, et al. (2010), adding spatial fixed effects can substantially reduce the bias from omitted variables in cross-section data.

\section{Hedonic Model Results}

Table 3 presents the key coefficient estimates describing the proximity of a home to a refuge. ${ }^{7}$ Models are estimated separately for the northeast and southeast regions and vary by the sample of homes included in the regression. Recall that a home must lie within three miles of a refuge, and that refuges must have a boundary within two miles of an urban area boundary to be

\footnotetext{
${ }^{7}$ Results for all covariates included in the regression models are presented in the appendix for an example model specification and geographic sample.
} 
included in the analysis. However, given the size and shape of many refuges, some portions of a refuge may be in an urbanized region while other portions are not. Given we expect the impacts of proximity to open space to only be capitalized into homes values where this amenity is scarce (i.e., in developed regions), we also restrict homes to be near the center of an urban area. Specifically, three geographically restricted samples are employed that require homes to be within either 5,8 or 10 miles of the nearest urbanized area's center (as well as within three miles of the boundary of a refuge). Restricting the sample geographically eliminates some refuges from the sample when urban boundaries are large and distance to the urban core (centroid) is greater than 5, 8 or 10 miles. The number of refuges included in each sample is noted directly in Table 3. Note results for the unrestricted sample including all 59 refuges is qualitatively similar to the results for the 10 mile sample which has 19 fewer refuges included.

The coefficients estimates for proximity of a house to a refuge are consistent across regions and model specifications, and are consistent with our expectations. Columns (1) to (3) in Table 3 present the coefficient estimates for models presented in equations (1), (2) and (3), respectively, using a geographically restricted sample of only homes within five miles of an urban center. As indicated in column (1), houses further from a refuge decrease in value, all else equal, although this effect diminishes as distance from the refuge is increased. The impact of proximity to a refuge is somewhat larger in the Southeast. The nonlinear effects of proximity to a refuge are highlighted by the model in column (2) that allows the effects of proximity to a refuge to vary in half-mile increments, and indicates that being within 0.5 miles of a refuge increases property value relative to the baseline (homes 2.5 to three miles away). However, the D0.5 location category is the only category for which proximity effects are apparent in both regions. Column (3) presents the coefficient estimate for equation (3) comparing homes within 0.5 miles of a refuge to those at any distance greater than 0.5 miles and up to three miles away, and underscores the previous model results.

Columns (4) to (9) in Table 3 relax the geographic restriction placed on the proximity of homes to the nearest urbanized area. Not surprisingly, the results indicate that the proximity impacts of being near a refuge are strongest for models that rely on samples closest to urban centers. This result is consistent with our expectation that open space amenities would be capitalized into housing values in areas where open space, especially permanently protected open space, is scarce. For example, when comparing similar models, we see that coefficient estimates 
fall approximately $50 \%$ in the northeast sample as the geographic scope of the sample is expanded from five to eight miles. The southeast shows some decline in average impacts as the geographic scope of the housing sample is increased, although coefficient estimates from like models across samples are not statistically different from each other at the $5 \%$ level. ${ }^{8}$

Taken as a whole, the results suggest that, for properties within 10 miles of an urban core, being located one-half mile of a refuge increases property value approximately five to ten percent as compared to homes further away. This range is consistent with studies that have identified open space benefits to homeowners in a particular market. For example, Boyle, Paterson and Poor (2002) and Neumann, Boyle and Bell (2009) examine the impacts of the Great Meadows refuge in Massachusetts and find that homes close to the refuge sell for approximately $7 \%$ more than homes approximately a mile further away. Our results are also consistent with Anderson and West (2006) estimate a $4.6 \%$ price increase for homes located one-half mile closer to preservation-style parks, but smaller than Lutzenhiser and Netusil (2001) who report a 16\% increase in value for homes located within 1,500 feet (approximately one-quarter mile) of a natural area. Our closest analytical unit is one-half mile, perhaps accounting for our smaller estimates.

\section{Amenity Value of Refuges}

Coefficient estimates from the models presented are used to calculate the average property value benefits that National Wildlife Refuges afford nearby homeowners. The impact of proximity to a refuge may be summarized in two ways. First is the marginal value or implicit price as defined by the derivative of the hedonic price function with respect to the proximity variable. For example, given the model specification presented in equation (3), the marginal value associated with a housing unit being located within 0.5 miles of a refuge as compared to further than 0.5 miles is computed by $\widehat{\beta_{1}} * H V$, where $\widehat{\beta_{1}}$ is the coefficient estimate for the variable $D 0.5$ and $H V$ is housing value. ${ }^{9}$

\footnotetext{
${ }^{8}$ Results for the samples including all refuges (no geographic restriction on the distance between homes and the urban core) are similar to the 10-mile sample. The exception is the continuous distance specification in the unrestricted northeast sample. The coefficients on continuous distance and its square are no longer statistically significant. However, the categorical variables describing proximity are statistically significant at the $1 \%$ level and indicate approximately a $2.5 \%$ increase in value for being located within 0.5 miles, similar to the 10 mile results.

${ }^{9}$ Given our model specification, the correct measure of the percentage impact of being within 0.5 miles of a refuge is $100\left[\exp \left(\beta_{1}-\frac{1}{2} V\left(\beta_{1}\right)\right)\right]$ percent (see Halvorsen and Palmquist, 1980). In practice, this transformation has a very modest impact and so we do not report it for ease of exposition.
} 
While marginal values are the most commonly reported statistic in hedonic housing studies, from the USFWS' perspective a more interesting statistic to compute is the total capitalized value associated with homes being proximate to refuges. Total capitalized value is the summation of the implicit capitalized prices over houses impacted by the refuge, and represents the market value of this aspect of housing as built and distributed spatially at the time of the data collection (Ihlanfeldt and Taylor, 2004). In other words, the total capitalized value represents the market value of this feature of houses ("proximity") as they are currently distributed around the refuge much in the same way we could compute the market capitalized value of in-ground swimming pools or any other particular housing feature. The total capitalized value is well suited to examining how current local tax revenues are impacted by the presence of a refuge since tax revenues are linked directly to property values. By applying the current millage rate to the total capitalized value associated with refuges, one can compute the tax revenue that is generated by the presence of refuges. ${ }^{10}$

Total capitalized values are computed based on the model in equation (3) that uses the sample of homes that are within eight miles of an urbanized area. All values are expressed in 2010 dollars. This model is chosen because it generally provided mid-point estimates among the models, allows a straightforward computation of total capitalized value and its standard error, and the coefficient estimates are more precise than for the other categorical distance model (given by equation 2). The estimates from all three models are however very similar with largely overlapping $95 \%$ confidence intervals.

To compute the total capitalized value for a refuge, we first compute the total capitalized value in each census block $b: T C V_{b}$. With sufficient information, we would compute $T C V_{b}$ by summing the estimated implicit price for each home in block $b$. However, the Census Bureau only collects data on individual home values for a one-in-six sample of households. As such, $T C V_{b}$ is computed by multiplying the average implicit price for homes in block $b$ that appear in our data by the total number of owner-occupied single-family detached homes in that block. The $T C V_{b}$ is summed over all blocks that are within 0.5 miles of a refuge and within eight miles of an urban area. Formally, block-level total capitalized value is computed as:

\footnotetext{
${ }^{10}$ It is important to be clear that total capitalized values cannot be interpreted as representing the welfare impacts of establishing a new refuge, or what would be lost if a refuge were removed and the land developed. A structural approach would be required to estimate the welfare change associated with any non-marginal change in open-space and development (Palmquist, 2005; Taylor, 2003).
} 


$$
T C V_{b}=\left(\sum_{i=1}^{I_{b}} \widehat{\beta_{1}} * H V_{i} / I_{b}\right) * N_{b}^{S F D}
$$

where $\widehat{\beta_{1}}$ is the estimated value for the coefficient of the categorical variable D0.5, $\mathrm{I}_{\mathrm{b}}$ is the total number of individual households observed in our data residing in single-family detached owneroccupied homes in block $b$, and $N_{b}^{S F D}$ is the total number of single-family detached owneroccupied housing units in block $b .{ }^{11}$ The term in parentheses in equation (5) is the average capitalized value for homes in block $b$ that appear in our regression data. Given an estimate for $T C V_{b}$ from equation (5), total capitalized value associated with proximity to refuge $\mathrm{R}, \mathrm{TCV}^{\mathrm{R}}$ is simply:

$$
T C V^{R}=\sum_{b}^{B_{0.5}^{R}} T C V_{b},
$$

where $B_{0.5}^{R}$ is the set of all blocks that are within 0.5 miles of the boundary of refuge $\mathrm{R}$ and also within the regression sample (e.g., blocks also within eight miles of an urban area).

Panel A in Table 4 presents the marginal and total capitalized values estimated for the set of refuges associated with the sample of homes within eight miles of an urban core. For the northeast region, the estimated average increase in value of a home located within 0.5 miles is approximately $\$ 16,000$ for a home valued at $\$ 250,000$, with a lower-bound estimate of approximately $\$ 5,000$. In the southeastern region, the marginal effect is larger than the northeast at $\$ 26,000$, however the $95 \%$ confidence intervals overlap for the two regions. The southeastern sample is dominated by refuges in Florida, and the open space premium associated with coastal refuges appears to be significant.

The total capitalized value for homeowners with 0.5 miles of a refuge and within 8 miles of an urban core is over $\$ 270$ million, averaging \$11 million per refuge (2010\$). Of course, the average value masks considerable heterogeneity among individual refuges. The final column in Panel A of Table 4 presents the range of per-refuge total capitalized values, which varies from as little as $\$ 330,000$ for a small refuge in New York state to over \$50 million for a large refuge in close proximity to many residential homes in Florida. Note, a common marginal value

\footnotetext{
${ }^{11} N_{b}^{S F D}$ is not directly reported by the Census (even within the confidential micro-data) and thus had to be estimated. First, we use the confidential Census micro-data to compute the proportion of owner-occupied, single-family detached houses among the total housing units contained in the Census one-in-six sample of households. We then multiply this proportion by the total number of housing units in a block, which is publicly available data, to arrive at our estimate of $N_{b}^{S F D}$. This computation assumes that the proportion of homes in the Census one-in-six sample of households that are owner-occupied, single-family detached is the same as for the entire population of households.
} 
coefficient is estimated for each refuge in a region and therefore the refuge-specific variation in capitalized values is due to the variation in density of development around refuges (and the size of the refuge), not variation in the estimated implicit value of proximity.

For context, we compare capitalized values to the recreational and ecosystem benefits afforded by refuges. Carver and Caudill (2006) estimate the net economic value (consumer surplus) of recreational visits to all refuges with more than 1,500 visitors per year in the northeast and southeast regions to be \$240 and \$280 million (2010\$), respectively, or approximately $\$ 2.7$ and \$2.1 million per refuge on average. Ingraham and Foster (2008) estimate that the ecosystem values provided by refuges in the northeast and southeast are quite large, averaging $\$ 2,909$ and $\$ 6,848$ per acre/year $(2010 \$)$, respectively. Of course, the annual net economic value of recreational visits and ecosystem benefits cannot be added to homeowner capitalization rates because the former are flow measures and the latter is a stock value. Furthermore, there is some double-counting across those homeowners that are included in the recreational value computations and whose capitalization rates include protections afforded by the nearby ecosystems (e.g. flood protection). Nonetheless, a few informative comparisons can be made to see how these values may complement each other.

We compare four refuges that Carver and Caudill (2006) individually analyzed and which are also included in our sample (see Panel B, Table 4). Visitation rates in 2006 for these four refuges varied from as little as 3,190 visitor days to as many as 590,743 visitor days.

Accordingly, the total annual net economic recreational benefits varied from as little as $\$ 61,000$ to as much as \$20 million (2010\$), respectively. The capitalized values for each refuge are reported in the last column of Table 4. Depending on the tax rate and density of homes surrounding the refuge, the annual property tax revenues for local jurisdictions can be equivalent or greater than the annual recreational benefit. This would be true for Waccamaw, John Heinz and Monomoy assuming typical tax rates of 10 to 20 mils, but not Wheeler which has very high recreational usage.

Comparing total capitalized values to a simple present value estimate of the flow of recreational benefits (see Table 4, footnote f for how this is calculated) highlights that benefits to homeowners should be considered in addition to recreational values, as they may be substantially larger than recreational benefits when total visitation to a refuge is relatively small (e.g., Waccamaw) or when visitors to a refuge are mostly non-local (e.g., Monomoy). This point is 
also underscored when considering the ecosystem benefits afforded by the refuges. Applying the average values of ecosystem benefits reported by Ingraham and Foster (2008) to the four refuges in Table 4 (\$2,909 and $\$ 6,848$ per acre/year) indicates that in some cases, the ecosystem benefits are in the hundreds of millions per year, swamping recreational and homeowner benefits due to the size of the refuge (e.g., Waccamaw, Wheeler and Monomoy). However, in other cases (e.g., John Heinz), recreational and homeowner benefits are more than double the ecosystem values. In this case, ignoring homeowner benefits would understate the economic value of the refuge substantially.

\section{Conclusions}

The benefits of preserved open space are important to understand as continued economic and political pressure lead to conversion of open space lands into other uses. We explore one of the potential economic benefits of the refuge system - specifically, the amenity value that living within close proximity of these protected open spaces and recreational areas confer to nearby homeowners. We focus on refuges located near urbanized areas in the eastern U.S., using a unique dataset that includes housing and location data defined at a very fine spatial resolution. Our results indicate a significant increase in the value of homes located within 0.5 miles of a refuge and within eight miles of an urban center. Specifically, these homes are valued between five and ten percent higher, on average, than homes further away. The capitalized value of these benefits for homeowners averages $\$ 11$ million per refuge and is estimated to be as $\$ 50$ million for individual refuges located in densely population areas (2010\$). Depending on local tax rates and the density of housing around a refuge, the presence of refuges can add up to $\$ 1$ million per annum to local tax revenues and be a significant component of the overall annual economic value generated by the refuge system.

It is also important to note that our coefficient estimates and results for capitalized values are based only on single family homes. The benefits that accrue to renters and owners of other housing units in close proximity to a refuge are left out of the above calculations. Assuming a positive value for individuals in these other housing types, our capitalization values are a lower bound on the total capitalization value in the local community.

The in-situ benefits that refuges confer to local homeowners and to the local jurisdictions whose revenue base is supplemented as a result of these increased home values are significant. 
To capture the full benefit of refuges, one would also need to consider recreational benefits for the broader community and ecosystem service values such as flood protection, water purification, and carbon storage as well. Carver and Caudill (2007) and Ingram and Foster (2008) offer agency-wide estimates of recreational and ecosystem values, respectively, and together with our estimates provide the basis for understanding the average impact of this important system of permanently protected open space across a broad geographic region. These values are useful for considering agency-wide program benefits when comprehensive case-bycase analyses are not possible or prohibitively expensive. 


\section{References}

Acharya, G., L.L. Bennett. 2001. "Valuing Open Space and Land-Use Patterns in Urban Watersheds" Journal of Real Estate Finance and Economics, March-May 2001, v. 22, iss. 23, pp. 221-37.

Anderson, Soren T., and Sarah E. West. 2006. “Open space, residential property values, and spatial context." Regional Science and Urban Economics 36:773-789.

Bark, R. H.; Osgood, D. E.; Colby, B. G.; Katz, G.; Stromberg, J. (2009). "Habitat Preservation and Restoration: Do Homebuyers Have Preferences for Quality Habitat?” Ecological Economics, v. 68, iss. 5, pp. 1465-75.

Bin, Okmyung, Jamie Brown Kruse, and Craig E. Landry. 2008. "Flood Hazards, Insurance Rates, and Amenities: Evidence from the Coastal Housing Market” Journal of Risk and Insurance 75(1): 63-82.

Bin, Okmyung and Steven Polasky. "Effects of Flood Hazards on Property Values: Evidence Before and After Hurricane Floyd.” Land Economics 80(2004): 490-500.

Bolitzer, B., and N.R. Netusil. 2000. The impact of open spaces on property values in Portland, Oregon. Journal of Environmental Management 59(3):185-193.

Boyle, Kevin J., Robert Paterson, and Joan P. Poor, 2002. "The Effect of National Wildlife Refuge Proximity on Selling Prices of Nearby Residential Properties," Staff Paper REP 507, Maine Agricultural and Forest Experiment Station, University of Main, Orono, Maine.

Carver, Erin and James Caudill. 2007. "Banking on Nature 2006: The Economic Benefits to Local Communities of National Wildlife Refuge Visitation". USFWS Division of Economics. Washington, DC.

Cho, S.H., Poudyal, N.C., Roberts, R.K. 2008. "Spatial Analysis of the Amenity Value of Green Open Space.” Ecological Economics, 66(2-3): 403-16.

Cho, Seong-Hoon; Clark, Christopher D.; Park, William M.; Kim, Seung Gyu (2009) "Spatial and Temporal Variation in the Housing Market Values of Lot Size and Open Space." Land Economics, 85(1): 51-73.

Deller, Steven C.; Tsai, Tsung-Hsiu; Marcouiller, David W.; English, Donald B. K. (2001) "The Role of Amenities and Quality of Life in Rural Economic Growth.” American Journal of Agricultural Economics, 83(2): 352-365.

Geoghegan, Jacqueline; Lynch, Lori; Bucholtz, Shawn. (2003) “Capitalization of Open Spaces 
into Housing Values and the Residential Property Tax Revenue Impacts of Agricultural Easement Programs." Agricultural and Resource Economics Review, 32(1):33-45.

Halvorsen R and Palmquist R. (1980). The interpretation of dummy variables in semilogarithmic equations, American Economic Review, 70(3): 474-475.

Ihlanfeldt, K. and L.O. Taylor. 2004. "Estimating the Economic Impacts of Environmentally Contaminated Properties in an Urban Area," Journal of Environmental Economics and Management, 47: 117-139.

Ingraham, M.W.; Foster, S.G. 2008. "The Value of Ecosystem Services Provided by the U.S. National Wildlife Refuge System in the Contiguous U.S." Ecological Economics, 67(4):60818.

Kiel, K. and J. Zabel. 1999. "The Accuracy of Owner-Provided House Values: The 1978-1991 American Housing Survey,” Real Estate Economics, 2: 263-298.

Kuminoff, N., C. Parmeter, J. Pope. 2010. "Which hedonic models can we trust to recover the marginal willingness to pay for environmental amenities?," Journal of Environmental Economics and Management, 60(3): 145-160.

Lutzenhiser, M., and N.R. Netusil. 2001. The Effect of Open Spaces on a Home's Sale Price. Contemporary Economic Policy 19(3): pp. 291-98.

McConnell, V. and Walls, M., 2005. The Value of Open Space: Evidence from Studies of Nonmarket Benefits, RFF Working Paper, available at: http://www.rff.org/rff/Documents/RFF-REPORT-Open\%20Spaces.pdf

Neumann, C.B., K.J. Boyle, and K.P. Bell. 2009. "Property price effects of a national wildlife refuge: Great Meadows National Wildlife Refuge in Massachusetts.” Land Use Policy, 26: 1011-1019.

Palmquist, Raymond. 2005. "Property value methods," in: Mäler KG, Vincent J (eds) Handbook of Environmental Economics, Elsevier, North Holland, Amsterdam.

Taylor, L.O. 2003. The Hedonic Method, in A Primer on the Economic Valuation of the Environment, eds. P. Champ, T. Brown and K. Boyle (Kluwer), pp 331-394.

Taylor, L.O. 2008. Theoretical Foundations and Empirical Developments in Hedonic Modeling, in Hedonic Methods in Housing Markets: Pricing Environmental Amenities and Segregation, eds. A. Baranzini, J. Ramirez, C. Schaerer and P. Thalmann. 
Table 1. National Wildlife Refuge Characteristics.

\begin{tabular}{lcc}
\hline & \multicolumn{1}{c}{$\begin{array}{c}\text { Northeast } \\
\text { Region }\end{array}$} & $\begin{array}{c}\text { Southeast } \\
\text { Region }\end{array}$ \\
\cline { 2 - 3 } & National Wildlife Refuge Characteristics & \\
\hline Number of Refuges & 34 & 25 \\
Total Acres & 33,454 & 328,211 \\
Mean Acres per refuge & 984 & 13,128 \\
(standard deviation) & $(2,196)$ & $(30,740)$ \\
No. refuges established before 1980 & 26 & 16 \\
& $(76.5 \%)$ & $(64 \%)$ \\
No. refuges established before 1990 & 31 & 18 \\
& $(91.2 \%)$ & $(72 \%)$ \\
No. refuges open to the public & $76.5 \%$ & $76.0 \%$ \\
No. refuges that have an auto tour route & $17.7 \%$ & $20.0 \%$ \\
Mean annual visitation per refuge & 134,195 & 173,851 \\
(standard deviation) & $(126,044)$ & $(306,303)$ \\
\hline \multicolumn{1}{c}{ Mean 2000 Census Demographics of Closest Urbanized Area } & \\
(standard deviations in parentheses) & \\
\hline Total area, square miles & 668 & 229 \\
& $(862)$ & $(293)$ \\
Total population, millions & 2.14 & 0.63 \\
& $(4.10)$ & $(1.17)$ \\
Population density per square mile & 2,127 & 2,010 \\
& $(1,016)$ & $(1,031)$ \\
Total housing units, in millions & 0.851 & 0.283 \\
& $(1.58)$ & $(0.51)$ \\
Housing density per square mile & 913 & 924 \\
& $(377)$ & $(433)$ \\
\hline
\end{tabular}

${ }^{a}$ Geospatial and characteristic data for all refuges were provided to the authors by the U.S. Fish and Wildlife Service. Summary statistics are provided for all refuges that are within two miles of the boundary of an urban area with a population greater than 50,000. Estimation samples reported later have fewer refuges due to further restrictions on housing proximity to the urban core.

b 2000 U.S. Census Summary File 4, available at http://www2.census.gov/census_2000/datasets/Summary_File_4/. 
Table 2. Housing Data and Descriptive Statistics ${ }^{\mathrm{a}}$

\begin{tabular}{|c|c|c|c|c|c|}
\hline \multirow[b]{2}{*}{ Variable Name } & \multirow[b]{2}{*}{ Description } & \multicolumn{2}{|c|}{ Northeast } & \multicolumn{2}{|c|}{ Southeast } \\
\hline & & $\begin{array}{l}\text { Median/ } \\
\text { Mean }\end{array}$ & Std Dev & $\begin{array}{l}\text { Median/ } \\
\text { Mean }\end{array}$ & Std Dev \\
\hline \multicolumn{6}{|c|}{ Housing Characteristics } \\
\hline House value & Owner occupied value (in $\$ 1,000$ s) & 195.2 & 148.8 & 114.6 & 101.0 \\
\hline Rooms & Total number of rooms & 6.00 & 1.17 & 5.44 & 0.83 \\
\hline Bedrooms & Number of bedrooms & 2.81 & 0.50 & 2.64 & 0.41 \\
\hline \multicolumn{6}{|c|}{ Neighborhood Characteristics } \\
\hline Pop_density & Population density $(1,000 /$ sq mile $)$ & 5.03 & 6.84 & 1.91 & 2.03 \\
\hline Fam_size & Median family size & 4.81 & 1.26 & 3.66 & 0.67 \\
\hline Children & $\%$ population 18 year or under & 0.26 & 0.08 & 0.25 & 0.09 \\
\hline Seniors & $\%$ population 65 year or above & 0.15 & 0.11 & 0.17 & 0.14 \\
\hline Income & Median household income $(\$ 1,000)$ & 57.9 & 29.2 & 41.9 & 19.2 \\
\hline Owner_occ & $\%$ housing units that are owner occupied & 0.63 & 0.24 & 0.65 & 0.20 \\
\hline Vac_seasonal & $\%$ vacant for seasonal, recreational, or occasional use & 0.35 & 0.39 & 0.27 & 0.32 \\
\hline Vac_sale & $\%$ vacant for sale & 0.17 & 0.27 & 0.22 & 0.28 \\
\hline Vac_other & $\%$ vacant for rent, migrant workers or other reasons & 0.38 & 0.37 & 0.42 & 0.34 \\
\hline SF_detached & $\%$ housing units that are single family detached & 0.63 & 0.34 & 0.68 & 0.26 \\
\hline Apartments & $\%$ housing units that are apartments & 0.23 & 0.26 & 0.17 & 0.21 \\
\hline \multicolumn{6}{|c|}{$\underline{\text { Geographic Characteristics }}$} \\
\hline D_refuge & $\begin{array}{l}\text { Distance in miles of a block centroid to the boundary } \\
\text { of the nearest refuge }\end{array}$ & 1.46 & 0.89 & 1.73 & 0.84 \\
\hline D_tran & $\begin{array}{l}\text { Distance in miles of a block centroid to the nearest } \\
\text { major highway }\end{array}$ & 2.69 & 2.35 & 8.56 & 12.76 \\
\hline D_water & $\begin{array}{l}\text { Distance in miles of a block centroid to the boundary } \\
\text { of the nearest coast }\end{array}$ & 9.91 & 14.54 & 4.61 & 6.83 \\
\hline
\end{tabular}




\begin{tabular}{|c|c|c|c|c|c|}
\hline \multirow[b]{2}{*}{ Variable Name } & \multirow[b]{2}{*}{ Description } & \multicolumn{2}{|c|}{ Northeast } & \multicolumn{2}{|c|}{ Southeast } \\
\hline & & Mean & $\overline{\text { Std Dev }}$ & Mean & $\overline{\text { Std Dev }}$ \\
\hline \multicolumn{6}{|c|}{ Geographic Characteristics, contd. } \\
\hline D_ua & $\begin{array}{l}\text { Distance in miles of a block centroid to the center } \\
\text { of the nearest urban area }\end{array}$ & 17.61 & 8.64 & 8.56 & 4.95 \\
\hline D_park & $\begin{array}{l}\text { Distance in miles of a block centroid to the nearest } \\
\text { Federal or State park boundary }\end{array}$ & 5.16 & 4.04 & 10.74 & 14.11 \\
\hline \multicolumn{6}{|c|}{ Land-use Cover, \% of blockgroup that is: } \\
\hline Water & open water & 0.01 & 0.02 & 0.02 & 0.04 \\
\hline Dev_open & developed, open space & 0.13 & 0.13 & 0.21 & 0.17 \\
\hline Low_den & developed, low density & 0.20 & 0.17 & 0.29 & 0.26 \\
\hline Med_den & developed, medium density & 0.22 & 0.21 & 0.09 & 0.11 \\
\hline High_den & developed high density & 0.11 & 0.18 & 0.02 & 0.04 \\
\hline Forest & forested cover & 0.18 & 0.21 & 0.11 & 0.16 \\
\hline Shrubs & shrubs and grasslands & 0.01 & 0.02 & 0.03 & 0.05 \\
\hline Pasture & pasture and cropland & 0.05 & 0.10 & 0.06 & 0.12 \\
\hline Wetlands & wetlands & 0.09 & 0.14 & 0.17 & 0.21 \\
\hline
\end{tabular}

${ }^{\mathrm{a}}$ Summary statistics for housing and neighborhood characteristics are computed using publicly available Census data at the blockgroup level of geography. In the empirical analysis, housing characteristics at the house-level and neighborhood characteristics at the block-level are used. Medians are reported for continues variables, means for categorical (0/1) variables. 
Table 3. Hedonic Price Model Results.

\begin{tabular}{|c|c|c|c|c|c|c|c|c|c|}
\hline & \multicolumn{9}{|c|}{ Maximum distance between centroid of census block and refuge boundary is: } \\
\hline & \multicolumn{3}{|c|}{5 miles } & \multicolumn{3}{|c|}{8 miles } & \multicolumn{3}{|c|}{10 miles } \\
\hline & $(1)$ & $(2)$ & $(3)$ & (4) & $(5)$ & $(6)$ & $(7)$ & $(8)$ & $(9)$ \\
\hline \multicolumn{10}{|c|}{ Panel A: Northeast Region } \\
\hline Distance & $\begin{array}{c}-0.141 * * * \\
(0.046)\end{array}$ & & & $\begin{array}{c}-0.074 * * * \\
(0.027)\end{array}$ & & & $\begin{array}{c}-0.043^{*} \\
(0.022)\end{array}$ & & \\
\hline Distance, squared & $\begin{array}{c}0.036 * * * \\
(0.013)\end{array}$ & & & $\begin{array}{c}0.021 * * * \\
(0.008)\end{array}$ & & & $\begin{array}{c}0.013 * * \\
(0.006)\end{array}$ & & \\
\hline D0.5 & & $\begin{array}{c}0.098 * * * \\
(0.036)\end{array}$ & $\begin{array}{c}0.101 * * * \\
(0.0309)\end{array}$ & & $\begin{array}{l}0.037 * \\
(0.021)\end{array}$ & $\begin{array}{c}0.051 * * * \\
(0.017)\end{array}$ & & $\begin{array}{c}0.023 \\
(0.019)\end{array}$ & $\begin{array}{c}0.034 * * \\
(0.014)\end{array}$ \\
\hline D1.0 & & $\begin{array}{l}-0.005 \\
(0.029)\end{array}$ & & & $\begin{array}{l}-0.020 \\
(0.018)\end{array}$ & & & $\begin{array}{c}-0.012 \\
(0.016)\end{array}$ & \\
\hline D1.5 & & $\begin{array}{l}-0.011 \\
(0.029)\end{array}$ & & & $\begin{array}{l}-0.015 \\
(0.017)\end{array}$ & & & $\begin{array}{l}-0.019 \\
(0.014)\end{array}$ & \\
\hline D2.0 & & $\begin{array}{c}0.009 \\
(0.024)\end{array}$ & & & $\begin{array}{l}-0.007 \\
(0.015)\end{array}$ & & & $\begin{array}{c}0.004 \\
(0.013)\end{array}$ & \\
\hline $\mathrm{D} 2.5$ & & $\begin{array}{l}-0.006 \\
(0.019)\end{array}$ & & & $\begin{array}{l}-0.018 \\
(0.012)\end{array}$ & & & $\begin{array}{l}-0.010 \\
(0.011)\end{array}$ & \\
\hline R-squared & 0.683 & 0.683 & 0.683 & 0.626 & 0.627 & 0.627 & 0.655 & 0.655 & 0.655 \\
\hline Observations & & 4,660 & & & 10,755 & & & 14,551 & \\
\hline Number of refuges & & 9 & & & 11 & & & 19 & \\
\hline \multicolumn{10}{|c|}{ Panel B: Southeast Region } \\
\hline Distance & $\begin{array}{c}-0.221 * * * \\
(0.045)\end{array}$ & & & $\begin{array}{c}-0.186 * * * \\
(0.029)\end{array}$ & & & $\begin{array}{c}-0.171 * * * \\
(0.025)\end{array}$ & & \\
\hline Distance, squared & $\begin{array}{c}0.057 * * * \\
(0.012)\end{array}$ & & & $\begin{array}{c}0.052 * * * \\
(0.008)\end{array}$ & & & $\begin{array}{c}0.044 * * * \\
(0.007)\end{array}$ & & \\
\hline D0.5 & & $0.101 * * *$ & $0.077 * * *$ & & $0.069 * * *$ & $0.0867 * * *$ & & $0.087 * * *$ & $0.082 * * *$ \\
\hline
\end{tabular}


Maximum distance between centroid of census block and refuge boundary is:

\begin{tabular}{|c|c|c|c|c|c|c|c|c|c|}
\hline & \multirow{2}{*}{\multicolumn{3}{|c|}{5 miles }} & \multirow{2}{*}{\multicolumn{3}{|c|}{8 miles }} & \multirow{2}{*}{\multicolumn{3}{|c|}{10 miles }} \\
\hline & & & & & & & & & \\
\hline & (1) & (2) & (3) & (4) & (5) & (6) & (7) & (8) & (9) \\
\hline \multicolumn{10}{|c|}{ Panel B: Southeast Region } \\
\hline \multirow{3}{*}{ D1.0 } & & $(0.035)$ & $(0.023)$ & & $(0.024)$ & $(0.0168)$ & & $(0.021)$ & $\overline{(0.015)}$ \\
\hline & & 0.038 & & & -0.009 & & & 0.017 & \\
\hline & & $(0.029)$ & & & $(0.020)$ & & & $(0.017)$ & \\
\hline \multirow{2}{*}{ D1.5 } & & -0.035 & & & $-0.042 * *$ & & & -0.009 & \\
\hline & & $(0.025)$ & & & $(0.017)$ & & & $(0.015)$ & \\
\hline \multirow{2}{*}{ D2.0 } & & -0.034 & & & $0.038 * * *$ & & & -0.019 & \\
\hline & & $(0.021)$ & & & $(0.014)$ & & & $(0.012)$ & \\
\hline \multirow[t]{2}{*}{ D2.5 } & & -0.023 & & & -0.019 & & & -0.005 & \\
\hline & & $(0.018)$ & & & $(0.012)$ & & & $(0.010)$ & \\
\hline R-squared & 0.612 & 0.612 & 0.611 & 0.639 & 0.639 & 0.639 & 0.624 & 0.624 & 0.624 \\
\hline Observations & & 6,970 & & & 13,926 & & & 18,134 & \\
\hline Number of refuges & & 16 & & & 21 & & & 21 & \\
\hline
\end{tabular}


Table 4. Marginal and Total Capitalized Values (2010\$). ${ }^{a}$

\section{Panel A: Regional Impacts}

\begin{tabular}{cccccc} 
& $\begin{array}{c}\text { Marginal Value } \\
\text { (95\% Conf. Interval) }\end{array}$ & $\begin{array}{c}\text { Total Capitalized } \\
\text { Value (millions) } \\
\text { (95\% Conf. Interval) }\end{array}$ & $\begin{array}{c}\text { Refuges } \\
\text { in } \\
\text { Sample }^{\mathbf{b}}\end{array}$ & $\begin{array}{c}\text { Average } \\
\text { Value per } \\
\text { Refuge }^{\mathbf{c}} \\
\text { (millions) }\end{array}$ & $\begin{array}{c}\text { Range }^{\mathbf{d}} \\
\text { (millions) }\end{array}$ \\
\hline Northeast & $\begin{array}{c}\$ 16,114 \\
(5,255-26,972)\end{array}$ & $\begin{array}{c}\$ 120.59 \\
(31.2-159.3)\end{array}$ & 11 & $\$ 10.97$ & $\$ 0.33 / \$ 42.07$ \\
Southeast & $\$ 27,447$ & $\begin{array}{c}\$ 153.85 \\
(17,023-37,871)\end{array}$ & $14^{\mathrm{e}}$ & $\$ 10.99$ & $\$ 0.66 / \$ 53.27$ \\
& & $(95.6-212.1)$ & & &
\end{tabular}

Panel B: Sample Refuge Comparisons

Net Economic

2006 Recreational Value

Refuge

(Acres)

Waccamaw

$(>55,000)$

John Heinz

(200)

Wheeler

$(>35,000)$

Monomoy

$(7,604)$

\section{(annual estimate /}

visitation

Region

(\% local) $^{\mathrm{e}}$

N. East

3,190

(90\%)

N. East

106,491

(72\%)

S. East

590,743

$(74 \%)$

S. East

31,660

$(10 \%)$ total present value ${ }^{\mathrm{f}}$ )

$\$ 61,000 / \$ 762,000$

$\$ 1.43 \mathrm{~m} / \$ 17.83 \mathrm{~m}$

$\$ 20.44 \mathrm{~m} / \$ 255.50 \mathrm{~m}$
Total Capitalized Value

(95\% confidence interval)

$\$ 6.66 \mathrm{~m}$

$(4.1-9.2)$

$\$ 28.88 \mathrm{~m}$

$(9.5-48.3)$

$\$ 29.87 \mathrm{~m}$

$(18.6-41.2)$

$\$ 3.66 \mathrm{~m}$

$(1.2-6.1)$

${ }^{a}$ All values are based on the model specification presented in equation (3) and the estimation sample that restricts homes to be within eight miles of the nearest urbanized area (coefficient estimates are presented in column 6, Table 2). See text for description of how marginal and total capitalized values are computed.

${ }^{\mathrm{b}}$ The number of refuges included in these calculations are less than those reported in Table 1 due to the sample restriction that homes in the sample also lie within 8 miles of the center of the nearest urban area. Furthermore, seven refuges in the southeast did not have homes within 0.5 miles (but do have homes within 3 miles) of the boundary of the refuge and within 8 miles of the urban center and thus are not included in the total capitalization computation.

${ }^{c}$ Average value is simply total capitalized value divided by the number of refuges in the sample.

${ }^{d}$ The range of total capitalized values are based on computations specific to each refuge as described by equation (6) in the text.

${ }^{\mathrm{e}}$ Reported by Carver and Caudill (2008). Local is defined as visitors living <30 miles from a refuge.

${ }^{\mathrm{f}}$ Derived from Carver and Caudill (2008). Total present value is simply the estimated annual value divided by an assumed $8 \%$ discount rate to reflect general homeowner mortgage rates in 2000 , the year in which the housing data was collected. 
Appendix Table A.1. Full Results for Sample Models. ${ }^{a}$

\begin{tabular}{|c|c|c|}
\hline \multirow[b]{2}{*}{ Variable Name } & \multicolumn{2}{|c|}{$\begin{array}{l}\text { Coefficient } \\
\text { (std error) }\end{array}$} \\
\hline & $\begin{array}{c}\text { Northeast } \\
\text { Region }\end{array}$ & $\begin{array}{c}\text { Southeast } \\
\text { Region }\end{array}$ \\
\hline \multicolumn{3}{|l|}{ Proximity to refuge } \\
\hline D0.5 & $\begin{array}{c}0.0365^{*} \\
(0.021)\end{array}$ & $\begin{array}{c}0.0686 * * * \\
(0.0239)\end{array}$ \\
\hline D1.0 & $\begin{array}{l}-0.020 \\
(0.018)\end{array}$ & $\begin{array}{c}-0.0086 \\
(0.0202)\end{array}$ \\
\hline D1.5 & $\begin{array}{l}-0.015 \\
(0.017)\end{array}$ & $\begin{array}{c}-0.0420^{* *} \\
(0.0168)\end{array}$ \\
\hline D2.0 & $\begin{array}{l}-0.007 \\
(0.015)\end{array}$ & $\begin{array}{c}-0.0375^{* * *} \\
(0.0143)\end{array}$ \\
\hline $\mathrm{D} 2.5$ & $\begin{array}{l}-0.018 \\
(0.012)\end{array}$ & $\begin{array}{l}-0.0191 \\
(0.0120)\end{array}$ \\
\hline \multicolumn{3}{|c|}{ NWR Characteristics } \\
\hline $\ln$ (visitation rates) & $\begin{array}{c}-0.0707 * * * \\
(0.0162)\end{array}$ & $\begin{array}{c}0.0441 * * \\
(0.0209)\end{array}$ \\
\hline Auto-tour route & ${ }^{\mathrm{b}}$ & $\begin{array}{c}-0.442 * * * \\
(0.167)\end{array}$ \\
\hline \multicolumn{3}{|c|}{ Housing Characteristics } \\
\hline Rooms & $\begin{array}{c}0.0106 \\
(0.0252)\end{array}$ & $\begin{array}{l}-0.0164 \\
(0.0231)\end{array}$ \\
\hline Rooms $^{2}$ & $\begin{array}{c}0.0058^{* * *} \\
(0.0019)\end{array}$ & $\begin{array}{c}0.0085^{* * *} * \\
(0.0017)\end{array}$ \\
\hline Bedrooms & $\begin{array}{c}0.0216 \\
(0.0343)\end{array}$ & $\begin{array}{l}-0.0468 \\
(0.0345)\end{array}$ \\
\hline Bedrooms $^{2}$ & $\begin{array}{c}0.0058 \\
(0.00517)\end{array}$ & $\begin{array}{c}0.0196 * * * \\
(0.00526)\end{array}$ \\
\hline \multicolumn{3}{|c|}{ Neighborhood Characteristics } \\
\hline Arealand & $\begin{array}{c}0.0081 \\
(0.0265)\end{array}$ & $\begin{array}{c}0.0062 \\
(0.0102)\end{array}$ \\
\hline Arealand $^{2}$ & $\begin{array}{l}-0.010 \\
(0.0103)\end{array}$ & $\begin{array}{c}-0.0012^{*} \\
(0.000615)\end{array}$ \\
\hline Pop_density & $\begin{array}{c}-0.0086^{* * * *} \\
(0.0015)\end{array}$ & $\begin{array}{c}-0.00777^{* * * *} \\
(0.0013)\end{array}$ \\
\hline Pop_density ${ }^{2}$ & $\begin{array}{c}7.91 \mathrm{e}-05^{* * * *} \\
(1.36 \mathrm{e}-05)\end{array}$ & $\begin{array}{c}2.17 \mathrm{e}-05^{* * * *} \\
(3.84 \mathrm{e}-06)\end{array}$ \\
\hline Fam_size & $\begin{array}{l}-0.0214 \\
(0.0170)\end{array}$ & $\begin{array}{c}0.0337 * * \\
(0.0164)\end{array}$ \\
\hline Fam_size ${ }^{2}$ & $\begin{array}{l}-0.0009 \\
(0.0027)\end{array}$ & $\begin{array}{c}-0.0080 * * * * \\
(0.0026)\end{array}$ \\
\hline Children & $\begin{array}{c}0.0007 \\
(0.0089)\end{array}$ & $\begin{array}{c}-0.0212 * * \\
(0.0085)\end{array}$ \\
\hline
\end{tabular}


Table A.1. Continued.

\begin{tabular}{|c|c|c|}
\hline Seniors & $\begin{array}{c}0.0303 * * * \\
(0.0087)\end{array}$ & $\begin{array}{c}0.0029 \\
(0.0083)\end{array}$ \\
\hline Income & $\begin{array}{c}0.0025^{* * *} * \\
(0.0002)\end{array}$ & $\begin{array}{c}0.0036^{* * * *} \\
(0.0002)\end{array}$ \\
\hline Income $^{2}$ & $\begin{array}{c}-2.22 \mathrm{e}-06^{* * * *} \\
(2.57 \mathrm{e}-07)\end{array}$ & $\begin{array}{c}-2.9 \mathrm{e}-06^{* * *} * \\
(3.52 \mathrm{e}-07)\end{array}$ \\
\hline Owner_occ ${ }^{2}$ & $\begin{array}{l}-0.137 \\
(0.141)\end{array}$ & $\begin{array}{l}0.0479 \\
(0.152)\end{array}$ \\
\hline Owner_occ ${ }^{2}$ & $\begin{array}{l}0.0990 \\
(0.093)\end{array}$ & $\begin{array}{l}0.0388 \\
(0.098)\end{array}$ \\
\hline Vac_seasonal & $\begin{array}{c}0.554 * * * \\
(0.114)\end{array}$ & $\begin{array}{c}0.786 * * * * \\
(0.200)\end{array}$ \\
\hline Vac_seasonal $^{2}$ & $\begin{array}{c}0.00819 \\
(0.187)\end{array}$ & $\begin{array}{l}-0.0243 \\
(0.482)\end{array}$ \\
\hline Vac_sale & $\begin{array}{c}0.179 \\
(0.206)\end{array}$ & $\begin{array}{c}0.594 * * * \\
(0.194)\end{array}$ \\
\hline Vac_sale ${ }^{2}$ & $\begin{array}{l}-0.192 \\
(0.538)\end{array}$ & $\begin{array}{l}-1.025^{*} \\
(0.548)\end{array}$ \\
\hline Vac_other & $\begin{array}{c}0.266 \\
(0.189)\end{array}$ & $\begin{array}{c}0.589 * * * \\
(0.160)\end{array}$ \\
\hline Vac_other ${ }^{2}$ & $\begin{array}{l}-0.191 \\
(0.541)\end{array}$ & $\begin{array}{c}-0.935^{* * * *} \\
(0.351)\end{array}$ \\
\hline Single_fam & $\begin{array}{c}-0.0002 \\
(0.0333)\end{array}$ & $\begin{array}{l}-0.146^{*} \\
(0.0750)\end{array}$ \\
\hline Apartments & $\begin{array}{l}-0.0251 \\
(0.0497)\end{array}$ & $\begin{array}{c}-0.0284 \\
(0.0918)\end{array}$ \\
\hline Geographic Cho & & \\
\hline D_ua & $\begin{array}{c}0.0088 \\
(0.0192)\end{array}$ & $\begin{array}{c}0.0685^{* * * *} \\
(0.0188)\end{array}$ \\
\hline D_ua ${ }^{2}$ & $\begin{array}{c}0.0026 \\
(0.0019)\end{array}$ & $\begin{array}{c}-0.0043^{* *} \\
(0.0019)\end{array}$ \\
\hline D_park & $\begin{array}{r}-0.00189 \\
(0.0024)\end{array}$ & $\begin{array}{l}-0.0019 \\
(0.0027)\end{array}$ \\
\hline D_park ${ }^{2}$ & $\begin{array}{l}4.09 \mathrm{e}-05^{*} \\
(2.22 \mathrm{e}-05)\end{array}$ & $\begin{array}{c}2.79 \mathrm{e}-05 \\
(2.59 \mathrm{e}-05)\end{array}$ \\
\hline D_highway & $\begin{array}{l}-0.0013 \\
(0.0022)\end{array}$ & $\begin{array}{c}0.0042 \\
(0.0027)\end{array}$ \\
\hline D_highway $^{2}$ & $\begin{array}{c}9.67 \mathrm{e}-06 \\
(2.43 \mathrm{e}-05)\end{array}$ & $\begin{array}{c}-5.73 \mathrm{e}-05 \\
(4.81 \mathrm{e}-05)\end{array}$ \\
\hline D_water & $\begin{array}{c}-0.00069 \\
(0.0013)\end{array}$ & $\begin{array}{l}0.0030 \\
(0.002)\end{array}$ \\
\hline D_water ${ }^{2}$ & $\begin{array}{r}-9.84 \mathrm{e}-06 \\
(9.94 \mathrm{e}-06)\end{array}$ & $\begin{array}{c}-2.74 \mathrm{e}-05^{* *} \\
(1.29 \mathrm{e}-05)\end{array}$ \\
\hline
\end{tabular}


Table A.1. Continued

\begin{tabular}{lcc}
\hline Land-use Cover Characteristics & & \\
Open water & 0.366 & 0.269 \\
& $(0.378)$ & $(0.241)$ \\
Dev_open & 0.0637 & $0.141^{* * *}$ \\
& $(0.0861)$ & $(0.0513)$ \\
Dev_med & -0.142 & 0.0460 \\
& $(0.0957)$ & $(0.127)$ \\
Dev_high & -0.137 & 0.0840 \\
& $(0.0964)$ & $(0.184)$ \\
Forest & $-0.197 * * *$ & 0.0524 \\
& $(0.0462)$ & $(0.0505)$ \\
Shrubs & -0.190 & -0.0856 \\
& $(0.192)$ & $(0.148)$ \\
Pasture & 0.0366 & $0.187 * * *$ \\
& $(0.0784)$ & $(0.0646)$ \\
Wetlands & -0.0560 & $0.137 * * *$ \\
& $(0.0613)$ & $(0.0477)$ \\
Constant & $11.72^{* * *}$ & $10.97 * * *$ \\
& $(0.133)$ & $(0.222)$ \\
Observations & & \\
R-squared & 10,755 & 13,926 \\
a.l & 0.627 & 0.639 \\
\hline
\end{tabular}

${ }^{a}$ All models presented are based on housing samples that lie within three miles of the nearest refuge boundary and eight miles of the center of the nearest urbanized center. Models including only D 0.5 are not reported here as full-model results were not released due to similarity among model coefficients for all other covariates within each region.

${ }^{\mathrm{b}}$ For confidentiality reasons, this coefficient estimate could not be released (very few refuges in the sample had a value $=1$ ). For both models, the coefficient estimate was positive and significant at the $5 \%$ level. 